\title{
Arbuscular Mycorrhizae Effects on Growth of Two Hawaiian Species: Indigenous Osteomeles anthyllidifolia (Rosaceae) and Invasive Psidium cattleianum (Myrtaceae) ${ }^{1}$
}

\author{
R. E. Koske $e^{2,3}$ and 7. N. Gemma ${ }^{2}$
}

\begin{abstract}
Two important plant species of Hawaici, the indigenous Osteomeles anthyllidifolia (Sm.) Lindl., a component of Hawai'i's most endangered habitat, and the highly invasive Psidium cattleianum Sabine were grown with or without arbuscular mycorrhizal fungi in a soilless mix at different soil-solution phosphorus $(\mathrm{P})$ levels. At $\mathrm{P}$ levels similar to those in the field $(0.007 \mathrm{mg} \mathrm{P} / \mathrm{liter})$, shoot biomass of inoculated plants of O. anthyllidifolia was $189 \%$ greater than that of controls, and that of P. cattleianum was $93 \%$ greater. Root weight of O. anthyllidifolia and leaf-tissue $\mathrm{P}$ of both species also were significantly higher in inoculated plants. At a higher concentration of soil-solution P $(0.020 \mathrm{mg}$ P/liter), inoculated plants of $O$. anthyllidifolia had $176 \%$ more biomass than controls, and those of $P$. cattleianum had $49 \%$ more. In a growth medium with soilsolution P equivalent to that of good agricultural soil ( $0.200 \mathrm{mg}$ P/liter), inoculated plants of $O$. anthyllidifolia were $101 \%$ larger than controls. Results suggest that presence of arbuscular mycorrhizal fungi is of vital importance to establishment of $O$. anthyllidifolia in Hawaiian soils and that their absence may limit $P$. cattleianum invasion of sites that are highly deficient in available P.
\end{abstract}

The successful establishment and growth of seedlings of many plant species in the field is greatly influenced by the presence and abundance of arbuscular mycorrhizal fungi in the soil (e.g., Reeves et al. 1979, Janos 1980b, Grime et al. 1987, Read and Birch 1988, St. John 1999). Arbuscular mycorrhizal fungi form mutualisic associations with the roots of the majority of plant species (Smith and Read 1997) and substantially enhance the growth of plants by greatly improving access to immobile nutrients (especially phosphorus but also copper and zinc) (Miyasaka and Habte 2001), an important benefit in soils low in available phosphorus (Smith and Read 1997). In addition, arbuscular mycorrhizal fungi increase the uptake of inorganic ni-

${ }^{1}$ Manuscript accepted 2 January 2006.

2 Department of Biological Sciences, University of Rhode Island, Kingston, Rhode Island 02881.

${ }^{3}$ Corresponding author: phone: 401-874-2629; fax: 401-874-5974; e-mail: rkoske@uri.edu.

Pacific Science (2006), vol. 60, no. 4:471-482

(C) 2006 by University of Hawai'i Press

All rights reserved trogen (Govindarajulu et al. 2005), improve drought tolerance of host plants (Auge 2001), and can provide protection against some pathogens (e.g., Pozo et al. 2002) and heavy metals (Meharg 2003). Because plant species and cultivars vary greatly in their capacity to grow vigorously in the absence of arbuscular mycorrhizal fungi, the presence or absence of a critical population of arbuscular mycorrhizal fungi (along with other biotic and abiotic factors) can play an important role in regulating the composition of the plant communities that form at particular sites (e.g., Reeves et al. 1979, Janos 1980b, Grime et al. 1987, Read and Birch 1988, St. John 1999, Richter and Stutz 2002, Stampe and Daehler 2003).

Although arbuscular mycorrhizal fungi have been noted in the roots of many Hawaiian species (e.g., Gemma et al. 1992, Koske et al. 1992), studies to assess their effect on the growth of important species in Hawai' $i$ are relatively few (e.g., Habte and Manjunath 1991, Miyasaka et al. 1993, Gemma et al. 2002, Stampe and Daehler 2003). In the study reported here we examined the mycorrhizal dependency of a native and an invasive species. 
Osteomeles anthyllidifolia (Sm.) Lindl. ('ūlei) is an indigenous perennial shrub occurring at 2-2,320 m elevation on the islands of $\mathrm{Ha}-$ wai' $i$, Maui, Kaua'i, Moloka'i, and $\mathrm{O}^{\prime}$ ahu in a variety of habitats (e.g., coastal cliffs, lava fields, and mesic forests), including the dry forest, Hawai'i's most endangered habitat (Wagner et al. 1990, Mehrhoff 1996). Psidium cattleianum Sabine grows as a shrub or small tree and is a troublesome invasive in tropical and subtropical areas throughout the world, including Hawai'i, Tahiti, Mauritius, Florida, and Norfolk Island (Cronk and Fuller 1995, Langeland and Burks 1998). The species was described by Smith (1985:200) as "the worst pest in Hawai'i's rain forests." Introduced to Hawai'i from Brazil as a fruit tree in about 1825 (Wagner et al. 1990), P. cattleianum ("strawberry guava") now occurs on Hawai'i, Kaua'i, Lana'i, Maui, Moloka'i, and $\mathrm{O}^{\prime}$ ahu at elevations between 150 and 1,300 m (Smith 1985), where it forms dense, monotypic stands that exclude native species.

In Hawai' $i$, the roots of $O$. anthyllidifolia and $P$. cattleianum are highly colonized by arbuscular mycorrhizal fungi, and both species were putatively classified as being highly dependent on the basis of field surveys (Koske et al. 1992), suggesting that they would be excluded from sites lacking a minimal population of arbuscular mycorrhizal fungi (Koske and Gemma 1997). If so, this would be of critical importance in the restoration of native sites by $O$. anthyllidifolia and could help in assessing the likelihood of sites being successfully invaded by $P$. cattleianum. The goal of this study was to evaluate the effect of arbuscular mycorrhizal fungi on growth of these two species at different levels of soilsolution phosphorus.

\section{MATERIALS AND METHODS}

\section{Plant Materials}

Seeds of $O$. anthyllidifolia were collected in the Auwahi area on Maui, Hawai'i, in December 1998, and seeds of $P$. cattleianum were collected on Wa'ahila Ridge near the University of Hawaíi at Mānoa on O'ahu in
August 1999. Seeds were stored at $4^{\circ} \mathrm{C}$ for 4 or 8 months (O. anthyllidifolia and P. cattleianum, respectively) and germinated in a tray of growth medium (ProMix BX, Premier Brands, Stamford, Connecticut 06902) under a combination of full-spectrum, high-output lamps (Gro-Lux and Vitalite) at an intensity of ca. $200 \mu$ ein for 6 weeks.

\section{Growth Medium, Planting and Treatments}

When seedlings were ca. $2 \mathrm{~cm}$ tall they were transplanted to tapered plastic containers $(\mathrm{Su}-$ per Cells, Steuwe and Sons, Corvallis, Oregon 97331) measuring $20.7 \mathrm{~cm}$ tall by $3.8 \mathrm{~cm}$ diam. and containing $165 \mathrm{ml}$ of a soilless growing medium consisting of four volumes of pasteurized quartz sand to one volume of milled Canadian sphagnum peat (ca. 32:1 wt:wt) (Bengeyfield 1989, Gemma et al. 1997). This inert medium was selected to minimize the variation in nutrients that is common in soil-based media, and it has been used for a variety of species in our facility since 1990. The $\mathrm{pH}$ of the medium was adjusted to 6.2 with lime. One plant was grown in each container. There was greater variation in the size of the seedling transplants of $P$. cattleianum than in those of $O$. anthyllidifolia, and this variability was reflected in the results. Plants of O. anthyllidifolia were grown for 115 days and those of $P$. cattleianum for 185 days. Each treatment was replicated five times.

Plants were grown at two or three levels of soil-solution phosphorus $(\mathrm{P})$ by the addition of rock phosphate $\left(30 \%\right.$ total $\mathrm{PO}_{4}, 3 \%$ available $\mathrm{PO}_{4}$; Robin Jones Phosphate, Nashville, Tennessee 37234) based on a P-sorption curve prepared for the soilless medium (Fox and Kamprath 1970). Soil-solution P levels of $0.007,0.020$, and $0.200 \mathrm{mg} /$ liter were used for $O$. anthyllidifolia and 0.007 and $0.020 \mathrm{mg} /$ liter for P. cattleianum. Response of plants to arbuscular mycorrhizal fungi at soil-solution P levels of 0.020 and $0.200 \mathrm{mg} /$ liter was of interest because these levels have been used to categorize the mycorrhizal dependency of a variety of tropical species (Habte and Manjunath 1991). For reference, highly productive agricultural soils permitting 
$95 \%$ of maximum yield typically have soilsolution P levels of ca. $0.200 \mathrm{mg} /$ liter (Fox 1981). The $0.007 \mathrm{mg} /$ liter concentration was included because it was similar to the average $\mathrm{P}$ concentration of native Hawaiian soils (Gemma et al. 2002). We lacked enough seedlings to grow plants of $P$. cattleianum at $0.200 \mathrm{mg} /$ liter.

After transplantation to containers, plants were illuminated with a $1,000-W$ metal halide bulb (ca. $350 \mu$ ein) for $14 \mathrm{hr} /$ day in a growth room (mean temperature $=25.6 \pm 3.4^{\circ} \mathrm{C}$ [SD]). All containers were moved every other day to a different position under the light to minimize variation. Plants of $P$. cattleianum showed signs of light-induced bleaching after 130 days and were returned to the lights used during germination.

Additional nutrients were supplied to seedlings of both species by watering with a dilute nutrient solution prepared from a complete fertilizer that included micronutrients (HICAL peat-lite 20-0-20, Grace-Sierra Horticultural Products Co., Milpitas, California 95035) amended with $\mathrm{MgSO}_{4}$. The watering solution contained $\mathrm{N}(25 \mathrm{ppm}), \mathrm{K}(21 \mathrm{ppm})$, $\mathrm{Ca}(7.5 \mathrm{ppm}), \mathrm{SO}_{4}$ (2.34 ppm), $\mathrm{Mg}(0.59$ ppm), B (0.050 ppm), Cu (0.025 ppm), Fe (0.025 ppm), Mn (0.014 ppm), Mo (0.003 $\mathrm{ppm})$, and $\mathrm{Zn}(0.004 \mathrm{ppm})$. The $\mathrm{pH}$ of this solution was adjusted to 6.3 with $\mathrm{KOH}$, and each container received ca. $10 \mathrm{ml}$ of the solution ca. every other day. Osteomeles anthyllidifolia did not require any additional fertilization. After 130 days, the growth of plants of $P$. cattleianum slowed; the strength of the watering solution was then doubled, and $\mathrm{P}$ was added to the watering solution (as $\mathrm{KH}_{2} \mathrm{PO}_{4}$ ) at a concentration of $2 \mathrm{ppm}$ and maintained until the end of the experiment. In addition, a one-time addition of a trace element mix (S.T.E.M., Scotts-Sierra Horticultural Products, Marysville, Ohio 43041) containing $\mathrm{S}, \mathrm{B}, \mathrm{Cu}, \mathrm{Fe}, \mathrm{Mn}, \mathrm{Mo}$, and $\mathrm{Zn}$ was given at that time by dissolving $0.60 \mathrm{~g}$ of the powder in 1 liter of water and dispensing $10 \mathrm{ml}$ to each container.

Plants were grown with and without arbuscular mycorrhizal fungi. The mycorrhizal inoculum consisted of sand dune soil col- lected from beneath plants of American beachgrass (Ammophila breviligulata Fern.) at Scarborough Beach in Rhode Island and stored for 2 months at ca. $4^{\circ} \mathrm{C}$. This crude inoculum was added at the rate of $100 \mathrm{~g} /$ liter of growing mix. Peat was mixed with the inoculum to maintain the same ratio as in the growth medium. Spores of Acaulospora scrobiculata Trappe, Glomus aggregatum Schenck \& Smith emend. Koske, Gigaspora gigantea (Nicol. \& Gerd.) Gerd. \& Trappe, Scutellospora erythropa (Koske \& Walker) Walker \& Sanders, S. pellucida (Nicol. \& Schenck) Walker \& Sanders, and S. persica (Koske \& Walker) Walker \& Sanders were present in the soil. Hyphae of other species of arbuscular mycorrhizal fungi were probably present in the dune sand, as were other microorganisms. Two of the species in the inoculum, $A$. scrobiculata and G. aggregatum (as G. fasciculatum [R.E.K., pers. obs.]), occur in Hawaiian soils (Huang et al. 1983, Koske and Gemma 1996). Arbuscular mycorrhizal fungi have extremely broad host ranges (Smith and Read 1997), and the majority of published growth studies have used fungal isolates or species (including commercially available inocula) that did not originate from field collections of the plant being studied. We used the sand dune inoculum because it is adapted to sandy soils and has been shown to be effective in colonizing well in the sand:peat medium, including other Hawaiian species (unpubl. obs.). This agrees with the observation that the effectiveness of arbuscular mycorrhizal fungi isolates often is greatest in soil types most similar to those of their origin (e.g., Lambert et al. 1980, Gianinazzi-Pearson et al. 1985, Henkel et al. 1989, Stahl et al. 1990, Sylvia et al. 1993, Clark 1997).

The control medium ("noninoculated") was prepared by using an equal amount of inoculum that had been steamed at $90^{\circ} \mathrm{C}$ for 1.5 $\mathrm{hr}$ on two consecutive days. To reestablish the arbuscular mycorrhizal fungi-free microflora, a filtrate obtained by mixing $100 \mathrm{~g}$ of inoculum in 1 liter of deionized water and passing it through filter paper (Whatman no. 1) was added to the noninoculated pots $(10 \mathrm{ml}$ per container). 
Assessment of Inoculation and P Level

Shoot dry matter was determined after drying plant samples for $24 \mathrm{hr}$ at $70^{\circ} \mathrm{C}$, and root dry matter was determined after root samples were air-dried at room temperature $\left(22^{\circ} \mathrm{C}\right)$ in an air-conditioned room until a constant weight was obtained (5 days). Roots were not oven-dried because they became too brittle for later staining and assessment of colonization. Because of the striking appearance of the leaves with P-deficiency symptoms (puckering and red color) in O. anthyllidifolia, the percentage of leaves on each plant with Pdeficiency symptoms was determined after 101 days. Such symptoms were absent from $P$. cattleianum, and its leaves were not counted. Leaf-tissue $\mathrm{P}$ of $P$. cattleianum was measured in disks $(6.3 \mathrm{~mm}$ diam.) removed from the youngest fully expanded leaves. For leaf-tissue $\mathrm{P}$ analysis of $O$. anthyllidifolia, two pinnules from the youngest fully expanded leaf on each plant were removed at the end of the experiment and combined for analysis of the concentration of leaf-tissue P (Habte and Byappanhalli 1998). Pinnules and disks were oven-dried $\left(60^{\circ} \mathrm{C}\right)$, weighed, and ashed $\left(500^{\circ} \mathrm{C} \times 4 \mathrm{hr}\right)$; the residue was dissolved in $10 \mathrm{ml}$ of $\mathrm{H}_{2} \mathrm{O}$, and leaf-tissue $\mathrm{P}$ was measured using the molybdenum blue method (Habte et al. 1987). Mycorrhizal colonization of airdried roots was determined using the gridline intersect method (Giovannetti and Mosse 1980) after clearing in $2.5 \% \mathrm{KOH}$ and staining with trypan blue (Koske and Gemma 1989).

\section{Statistical Analysis}

Data were tested for normal distribution before analysis using Lilliefors test, and data that were not normally distributed were $\log$ transformed using the formula $\ln (100 \mathrm{X})$. Percentage data were arcsin-transformed. Data were then analyzed using analysis of variance (ANOVA) (Statview [SAS 1999]). Mycorrhizal dependency (MD) (Plenchette et al. 1983) at each soil-solution P level was calculated by the formula $\mathrm{MD}=100 \times$ (shoot dry weight mycorrhizal plants - shoot dry weight control plants)/shoot dry weight inoculated plants.

\section{Testing of Hawaiian Soils}

Two soil samples from the root zone of $O$. anthyllidifolia were tested for soil-solution $\mathrm{P}$ (Fox and Kamprath 1970): one each from Auwahi (Maui) and Hawai'i Loa (O'ahu). In addition, two soil samples were collected from Auwahi beneath plants of Dodonaea viscosa Jacq. growing less than $10 \mathrm{~m}$ from plants of O. anthyllidifolia. Four native Hawaiian soils in which $P$. cattleianum was growing were tested. All samples were from the island of O'ahu: two from Wa'ahila Ridge, one from Hawai'i Loa, and one from the Mānoa Cliff Trail on Mt. Tantalus.

\section{RESULTS}

Growth and leaf tissue $\mathrm{P}$ levels were increased in both species by inoculation with arbuscular mycorrhizal fungi, but the extent of the effect varied between species and at different soil-solution P levels.

\section{Osteomeles anthyllidifolia}

Growth of shoots was significantly increased by inoculation with arbuscular mycorrhizal fungi (ANOVA, $F=38.9$, df $=1, P<.001$ ) and by increasing the soil $\mathrm{P}$ concentration (ANOVA, $\quad F=49.3, \quad \mathrm{df}=2, \quad P<.001$ ) (Figure 1A). Shoots of inoculated plants were $189 \%$ larger than those of noninoculated plants at $0.007 \mathrm{mg} \mathrm{P} /$ liter, $176 \%$ at $0.020 \mathrm{mg} \mathrm{P} /$ liter, and $101 \%$ at $0.200 \mathrm{mg}$ $\mathrm{P} /$ liter. There was no significant effect of interaction between inoculation and soilsolution P concentration on shoot growth; the positive benefits of inoculation did not increase with higher levels of $\mathrm{P}$. Linear regressions for shoot weight versus soil-solution $\mathrm{P}$ were significant for inoculated $\left(r^{2}=0.801\right.$, $m=0.689 \pm 0.094, P<.001)$ and noninoculated plants $\left(r^{2}=0.807, m=0.439 \pm 0.061\right.$, $P=.013)$ (regression lines not shown). Using the equation of the regression lines, it was calculated that a soil-solution $\mathrm{P}$ level of $0.113 \mathrm{mg} /$ liter would be necessary for noninoculated plants to match the growth of inoculated plants at a soil-solution P level of $0.008 \mathrm{mg} /$ liter (the average for the field col- 

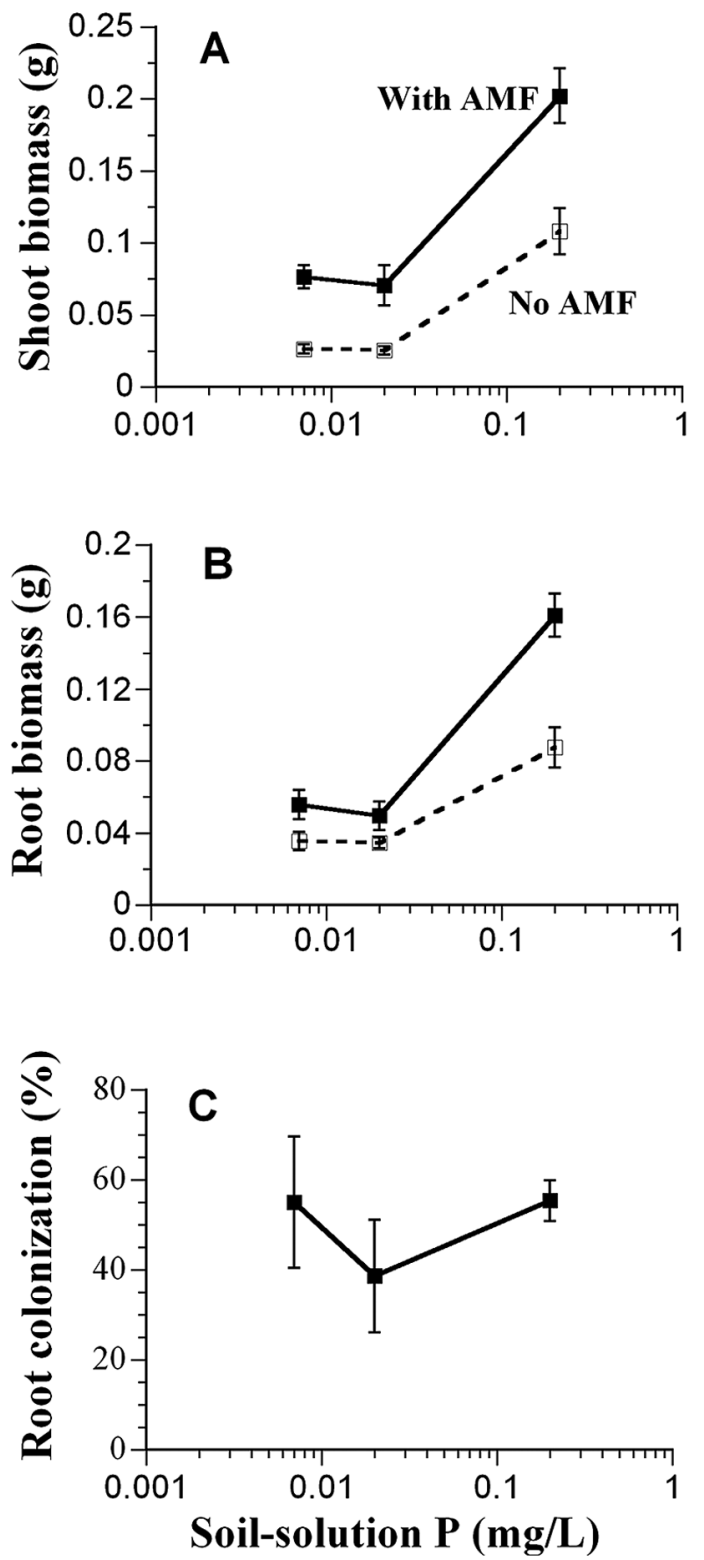

Figure 1. Response of Osteomeles anthyllidifolia to inoculation with a mixture of arbuscular mycorrhizal fungi (AMF) at three levels of soil-solution P. A, Shoot biomass; $B$, root biomass (air dry weight); $C$, root colonization (percentage). Each point represents the average of five plants. Bars indicate SE. lections of soil from this plant). The mycorrhizal dependency of plants was $76 \%$ at the lowest soil-solution $\mathrm{P}$ concentration, $70 \%$ at $0.020 \mathrm{mg} \mathrm{P} /$ liter, and $46 \%$ at $0.007 \mathrm{mg} \mathrm{P} /$ liter.

Roots of inoculated plants were significantly larger than those of noninoculated plants (47 to $85 \%$ ) (ANOVA, $F=28.4$, $\mathrm{df}=1, P<.001)$, and soil-solution $\mathrm{P}$ had a significant positive effect as well (ANOVA, $F=70.0, \quad \mathrm{df}=2, \quad P<.001) \quad($ Figure $1 B)$. There was a significant interaction effect (ANOVA, $F=7.5, \mathrm{df}=2, P=.003$ ) between inoculation and soil-solution $\mathrm{P}$ concentration on root growth; with more $\mathrm{P}$, the positive effect of arbuscular mycorrhizal fungi on root growth increased. Root colonization by arbuscular mycorrhizal fungi ranged from a mean of $39 \%$ in plants grown at $0.020 \mathrm{mg} \mathrm{P} /$ liter to $55 \%$ in the root of plants grown at $0.007 \mathrm{mg}$ P/liter (Figure $1 C)$. No significant effect of soil-solution $\mathrm{P}$ on extent of colonization was detected. None of the noninoculated plants formed mycorrhizae.

Leaf-tissue $\mathrm{P}$ was significantly increased by inoculation (ANOVA, $F=311.9, \quad \mathrm{df}=1$, $P<.001)$ but not by soil-solution $\mathrm{P}$ (ANOVA, $F=13.6, \mathrm{df}=2, P=.148$ ) (Figure $2 A$ ). Depending on the soil-solution P level, inoculated plants had leaf-tissue $\mathrm{P}$ concentrations that were 2.85 to 5.73 times those of the noninoculated plants. The interaction between inoculation and soil-solution $\mathrm{P}$ was not significant; with more $\mathrm{P}$, the extent of the positive effect of arbuscular mycorrhizal fungi on leaf-tissue $\mathrm{P}$ did not increase significantly.

The number of leaves per plant was significantly increased by inoculation (ANOVA, $F=15.2, \mathrm{df}=1, P<.001)$ and by increasing soil-solution $\mathrm{P}$ levels (ANOVA, $F=22.6$, $\mathrm{df}=1, P<.001) \quad($ Figure $2 B)$. The total number of leaves per plant ranged from $22 \%$ more on inoculated plants than on noninoculated plants at $0.020 \mathrm{mg} \mathrm{P} /$ liter to $87 \%$ more at $0.200 \mathrm{mg} \mathrm{P} /$ liter. There was a significant interaction between $\mathrm{P}$ level and inoculation (ANOVA, $F=12.4$, $\mathrm{df}=2, P=.028$ ); with more $\mathrm{P}$, the positive effect of arbuscular mycorrhizal fungi on the number of leaves increased. 

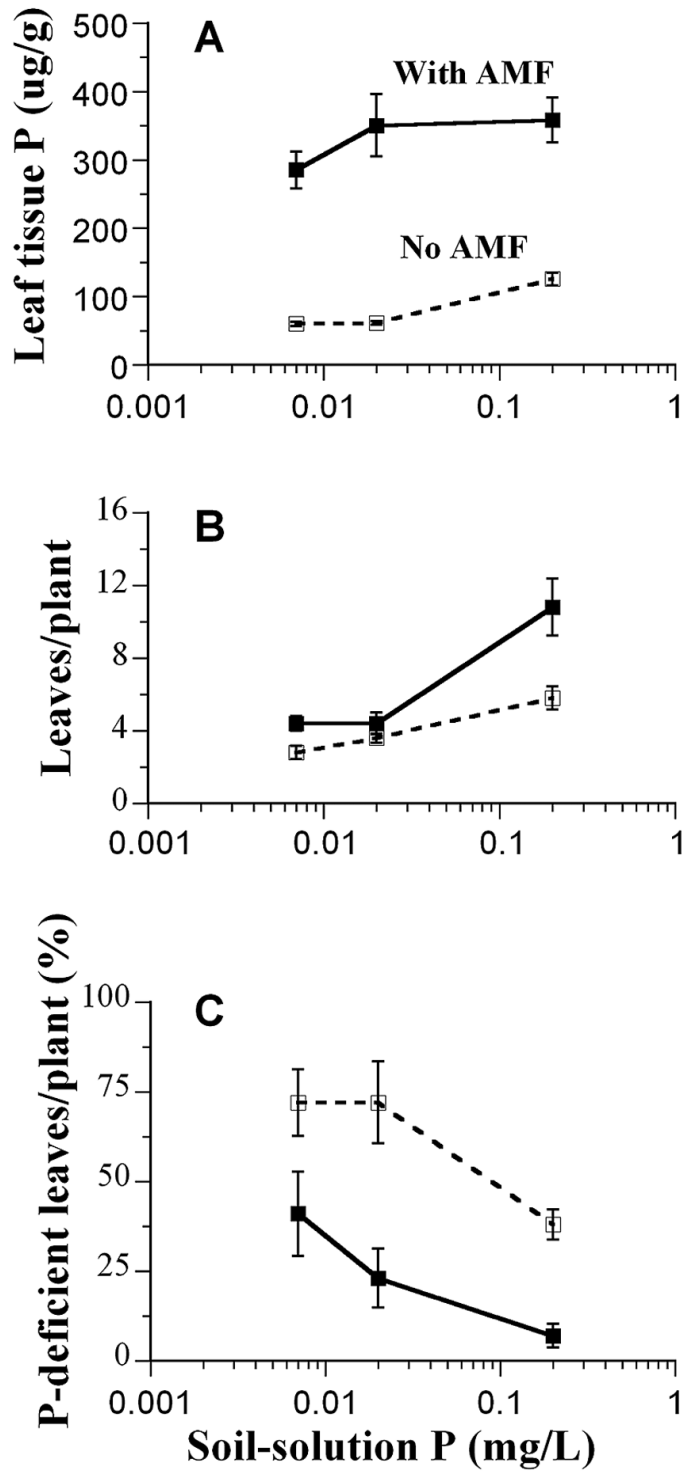

Figure 2. Effect of inoculation with arbuscular mycorrhizal fungi (AMF) on Osteomeles anthyllidifolia grown at three soil-solution $\mathrm{P}$ levels. $A$, Leaf-tissue $\mathrm{P} ; B$, total number of leaves per plant; $C$, percentage of leaves showing P-deficiency symptoms. Bars indicate SE.

The incidence of P-deficiency symptoms was significantly reduced by inoculation (ANOVA, $F=22.1, \mathrm{df}=1, P<.001$ ) and by increasing soil-solution $\mathrm{P}$ levels (ANOVA, $F=8.4, \mathrm{df}=1, P=.016)$. The incidence of deficiency symptoms in leaves of inoculated plants ranged from $43 \%$ (lowest $\mathrm{P}$ level) to $8 \%$ (highest $\mathrm{P}$ level), and symptoms were present in noninoculated plants in $72 \%$ of the leaves at the two lower soil P levels and in $38 \%$ of the leaves at $0.200 \mathrm{mg} \mathrm{P} /$ liter (Figure $2 C$ ). The interaction between $\mathrm{P}$ level and inoculation on deficiency symptoms was not significant; with more $\mathrm{P}$, the positive effect of arbuscular mycorrhizal fungi on the percentage of P-deficient leaves did not increase.

\section{Psidium cattleianum}

Inoculation significantly enhanced the shoot biomass of $P$. cattleianum (ANOVA, $F=11.1$, $\mathrm{df}=1, P=.005)$. On average, inoculated plants grown at $0.007 \mathrm{mg}$ P/liter weighed $93 \%$ more than noninoculated plants, and those grown at $0.020 \mathrm{mg} \mathrm{P} /$ liter were $49 \%$ larger (Figure $3 A$ ). Increased levels of soil $\mathrm{P}$ alone also had significant positive effects on shoot biomass (ANOVA, $F=8.2, \mathrm{df}=1$, $P=.001$ ), but the interaction between inoculation and $\mathrm{P}$ level was not significant; with more $\mathrm{P}$, the positive effect of arbuscular mycorrhizal fungi on shoot biomass did not increase. The mycorrhizal dependency of plants was high (64\%) at the lowest soilsolution P concentration but lower (33\%) at the higher concentration.

Although on average inoculated plants grown at a soil-solution P level of $0.007 \mathrm{mg} /$ liter had $96 \%$ larger root systems than noninoculated ones, and those at $0.020 \mathrm{mg}$ P/liter were $17 \%$ larger (Figure 3B), a large variation within treatments prevented statistical significance from being demonstrated. For the same reason, no effect of soil-solution $\mathrm{P}$ levels alone on root biomass was detected. Colonization of roots by arbuscular mycorrhizal fungi was low in the inoculated plants (mean $3.4 \% \pm 2.2 \quad[\mathrm{SD}]$ at low $\mathrm{P}$ and $3.3 \% \pm 2.1$ at higher $\mathrm{P}$ ) and was absent from the noninoculated ones. No significant differences in colonization resulted from the two levels of soil-solution P.

Leaf-tissue $\mathrm{P}$ levels were significantly higher in inoculated plants (ANOVA, $F=43.7, \mathrm{df}=1, P<.001)$, and increased 

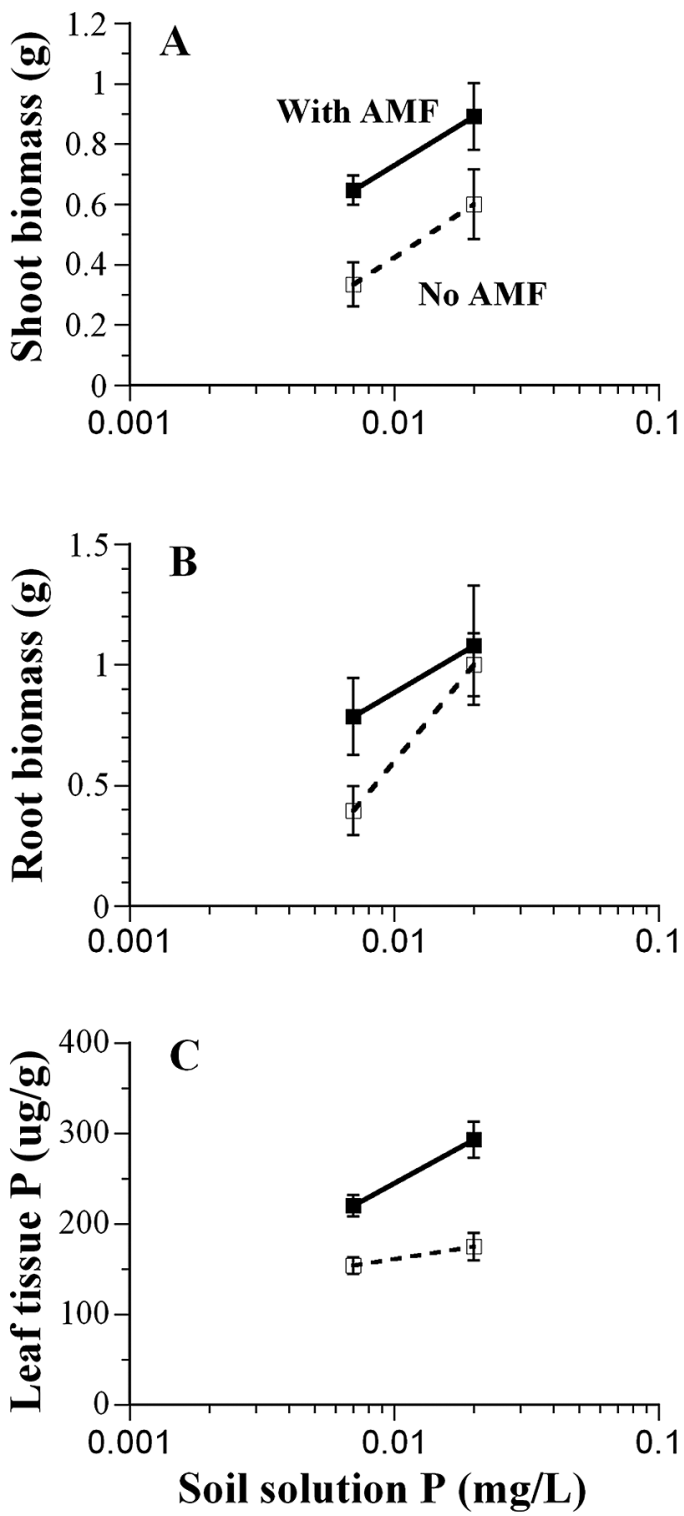

Figure 3. Response of Psidium cattleianum to inoculation with a mixture of arbuscular mycorrhizal fungi (AMF) at two levels of soil-solution P. $A$, Shoot biomass; $B$, root biomass (air dry weight); $C$, leaf-tissue $\mathrm{P}$. Each point represents the average of five plants. Bars indicate SE.

levels of soil $\mathrm{P}$ alone also had significant positive effects on leaf P (ANOVA, $F=11.2$, $\mathrm{df}=1, P=.015)$ (Figure $3 C$ ). The interaction between inoculation and $\mathrm{P}$ level was not significant (ANOVA, $F=3.5, \mathrm{df}=1$,
$P=.080$ ); with more $\mathrm{P}$, the positive effect of arbuscular mycorrhizal fungi on leaf $\mathrm{P}$ did not increase significantly.

\section{Soil Samples}

Soil-solution $\mathrm{P}$ levels in samples from the root zone of $O$. anthyllidifolia were $0.009 \mathrm{mg} /$ liter ( $\mathrm{O}^{\prime} \mathrm{ahu}$ ) and $<0.001 \mathrm{mg} / \mathrm{liter}$ (Maui). The two samples from root zones of $D$. viscosa near O. anthyllidifolia had soil-solution $\mathrm{P}$ levels of 0.009 and $0.014 \mathrm{mg} /$ liter. The mean of the four samples was $0.008 \pm 0.005$ (SD) $\mathrm{mg} \mathrm{P} /$ liter. The mean soil-solution $\mathrm{P}$ in native soils collected from the root zone of $P$. cattleianum was $0.014 \pm 0.002$ (SD) $\mathrm{mg}$ /liter. Soil-solution P levels for the Wa'ahila Ridge samples were 0.035 and $<0.001 \mathrm{mg} /$ liter, and 0.015 and $0.004 \mathrm{mg} /$ liter, respectively, for the samples from Hawai'i Loa and the Mānoa Cliff Trail.

\section{DISCUSSION}

The high mycorrhizal dependency values of $O$. anthyllidifolia and $P$. cattleianum in the treatments with soil-solution $\mathrm{P}$ values similar to those of native Hawaiian soils (Gemma et al. 2002) and previous observations on the presence of arbuscular mycorrhizal fungi in root samples (Koske et al. 1992) suggest that seedlings of both species would be likely to grow poorly in most native soils in the absence of arbuscular mycorrhizal fungi (Habte and Manjunath 1991, Gemma et al. 2002).

Because disturbed or nonvegetated sites are likely to have severely reduced populations of arbuscular mycorrhizal fungi (e.g., Moorman and Reeves 1979, Read and Birch 1988, Thompson 1994, Koske and Gemma 1997), it may be useful to add arbuscular mycorrhizal fungi to sites when $O$. antbyllidifolia or other highly dependent species are planted in such areas (e.g., Janos 1980b, Miller 1985, Gemma and Koske 1997, St. John 1999, Korb et al. 2004). Other native dry-forest species (e.g., Acacia koa Gray, Sophora chrysophylla (Salisb.) Seem., Dodonaea viscosa Jacq., and Colubrina oppositifolia Brongn. ex $\mathrm{H}$. Mann) also have high mycorrhizal dependency when grown in soils with low soil- 
solution P (Miyasaka et al. 1993, Koske and Gemma 1995, Gemma et al. 2002) and are likely to benefit similarly from inoculation (Miyasaka and Habte 2001). Arbuscular mycorrhizal fungi may be particularly important in this habitat because of the increase in drought tolerance that they provide (Auge 2001). In a study involving a turf grass grown in the same medium used in the study reported here, inoculated plants were $62 \%$ less stressed by drought than were the noninoculated plants (Gemma et al. 1997).

The preference of the invasive $P$. cattleianum for establishing in vegetated sites (Huenneke and Vitousek 1990) may reflect the benefits of having an arbuscular mycorrhizal fungi community in place when plant propagules arrive (Read and Birch 1988, Korb et al. 2004), although other biotic and abiotic factors (e.g., exposure, soil moisture) may be more important. Roots of seedlings that establish in sites vegetated with mycorrhizal species (as are most Hawaiian plants [Gemma et al. 1992, Koske et al. 1992]) can make contact with the existing, extensive network of arbuscular mycorrhizal fungi hyphae (nourished by the roots of native plants) and rapidly form a mycorrhizal association (Read and Birch 1988, Gemma and Koske 1997, Miller 2001).

The importance of the early association of roots of an invasive species with arbuscular mycorrhizal fungi hyphae in the soil is seen in the success of Centaurea maculosa Lam. (spotted knapweed) in invading native grasslands (Callaway et al. 2004). When seedlings of C. maculosa contact the hyphal network, they quickly benefit from greatly increased uptake of $\mathrm{P}$ and, possibly, from the transfer of carbon compounds from competing native species, growing nearly twice as fast as nonmycorrhizal seedlings (Zabinski et al. 2002, Carey et al. 2004). The growth response of $P$. cattleianum to inoculation at the lower $\mathrm{P}$ level in the study reported here was similar to that by C. maculosa. These results and those with other species (e.g., Reeves et al. 1979, Korb et al. 2004) suggest that $P$. cattleianum would not be an aggressive invader in low-P sites with subcritical populations of arbuscular mycorrhizal fungi (and see later in this section). Schmidt and Scow (1986) earlier proposed that the successful invasion of the Galápagos Islands by P. guajava L., the source of guava fruit, was dependent upon the presence of arbuscular mycorrhizal fungi in the soil, although no measurements of soilsolution P were made. In greenhouse studies $P$. guajava was highly dependent upon arbuscular mycorrhizal fungi (Janos 1980a, Estrada-Luna et al. 2000). The mycorrhizal dependency of $P$. cattleianum appears to be less than that of another widespread invasive species in Hawai'i, Leucaena leucocephala (Lam.) de Wit, which is unable to maintain growth in the absence of arbuscular mycorrhizal fungi at the lowest level of soil-solution $\mathrm{P}$ used in the study reported here (Habte and Manjunath 1987). However, because the growth response of plants to arbuscular mycorrhizal fungi (and measurement of mycorrhizal dependency) is greatly influenced by growing conditions, arbuscular mycorrhizal fungi populations used in the study, and duration of the experiments (e.g., Daft and Hogarth 1983, Aziz and Habte 1989, Gemma et al. 2002), strict comparisons between mycorrhizal dependency values may be misleading.

In the study reported here, extent of root colonization was not a good predictor of arbuscular mycorrhizal fungi effects. Although the roots of $O$. anthyllidifolia were highly colonized by arbuscular mycorrhizal fungi, those of P. cattleianum were not, unlike the high levels in occurring in field-collected samples of the latter species (Koske et al. 1992). The cause for the lower colonization of $P$. cattleianum is unknown but may be related to culturing conditions. The species is less tolerant of cool temperatures than is $O$. anthyllidifolia (Wagner et al. 1990), and the temperature during the study may have been unfavorable for extensive colonization of roots (e.g., Bentivenga and Hetrick 1992). The properties of the growth medium also may have inhibited synthesis of the symbiosis in this host (Gemma and Koske 1997, Corkidi et al. 2004). The low level of colonization did not appear to result from poor growth of the plants; with the reduction in light intensity and increase in fertilization, plants appeared to be healthy, and growth 
was good (mean height of $11.5 \mathrm{~cm}$ in inoculated plants in the $0.020 \mathrm{mg} \mathrm{P} /$ liter treatment at the end of the experiment) and without signs of nutrient deficiencies.

Although plant responses to inoculation with arbuscular mycorrhizal fungi typically increase with increasing colonization up to a point (Clapperton and Reid 1992), low levels of colonization do not necessarily correlate with reduced benefits. For example, in apple (Malus pumila Mill.), shoot biomass was $354 \%$ greater in inoculated plants than in noninoculated ones when roots had just 6\% colonization (Plenchette et al. 1982). Colonization levels of 1.5 to $6.6 \%$ in field and greenhouse trials with cool-season grasses resulted in significant increases in growth $(31 \%$ more), flowering $(67 \%)$, drought tolerance (62\%), leaf chlorophyll (48\%), and leaf-tissue P (203\%) (Gemma and Koske 1989, 1997, Gemma et al. 1997). Root branching and growth in other species were increased by up to $59 \%$ and $120 \%$, respectively, merely by contact with arbuscular mycorrhizal fungi hyphae, before colonization (Gemma and Koske 1988). In terms of effects on growth of plants, the final extent of colonization appears to be less important than how soon after seed germination that the roots become colonized (Miller 2001).

The importance of arbuscular mycorrhizal fungi to $O$. anthyllidifolia and $P$. cattleianum in the field may be greater than suggested by our growth-room studies because some of the benefits of arbuscular mycorrhizal fungi, such as improved drought tolerance and protection against soil pathogens (e.g., St.-Arnaud et al. 1994, Auge 2001, Pozo et al. 2002), are likely to be more important under field conditions (see Gemma et al. 1997). Because increased colonization of roots by arbuscular mycorrhizal fungi often is highly correlated with improved growth of plants (Clapperton and Reid 1992), the failure of seedlings of P. cattleianum to be colonized by arbuscular mycorrhizal fungi in the study reported here to an extent similar to that in the field suggests that field-grown seedlings would benefit more than did the study plants (i.e., have higher mycorrhizal dependency at both soilsolution P levels).

\section{ACKNOWLEDGMENTS}

We thank Fred Pollnac for technical assistance; Alvin Yoshinaga for information on seed storage and germination; Lloyd Loope, Art Medieros, and Chuck Chimera for assistance in collecting seeds and soil samples from Maui; and the reviewers for their helpful comments.

\section{Literature Cited}

Auge, R. M. 2001. Water relations, drought and vesicular-arbuscular mycorrhizal symbiosis. Mycorrhiza 11:3-42.

Aziz, T., and M. Habte. 1989. The sensitivity of three vesicular-arbuscular mycorrhizal species to simulated erosion. J. Plant Nutr. 12:859-869.

Bengeyfield, W. H., ed. 1989. Specifications for a method of putting green construction. United States Golf Association, Far Hills, New Jersey.

Bentivenga, S., and B. A. D. Hetrick. 1992. Seasonal and temperature effects on mycorrhizal activity and dependence of cooland warm-season tallgrass prairie grasses. Can. J. Bot. 70:1596-1602.

Callaway, R. M., G. C. Thelen, S. Barth, P. W. Ramsey, and J. E. Gannon. 2004. Soil fungi alter interactions between the invader Centaurea maculosa and North American natives. Ecology 85:1062-1071.

Carey, E. V., M. J. Marler, and R. M. Callaway. 2004. Mycorrhizae transfer carbon from a native grass to an invasive weed: Evidence from stable isotopes and physiology. Plant Ecol. 172:133-141.

Clapperton, M. J., and D. M. Reid. 1992. A relationship between plant growth and increasing VA mycorrhizal inoculum density. New Phytol. 120:227-234.

Clark, R. B. 1997. Arbuscular mycorrhizal adaptation, spore germination, root colonization, and host plant growth and mineral acquisition at low $\mathrm{pH}$. Plant Soil 192:15-22.

Corkidi, L., E. B. Allen, D. Merhaut, M. F. Allen, J. Downer, J. Bohn, and M. Evans. 2004. Assessing the infectivity of commercial mycorrhizal inoculants in plant 
nursery conditions. J. Environ. Hortic. 22:149-154.

Cronk, Q. C. B., and J. L. Fuller. 1995. Plant invaders. Chapman and Hall, London.

Daft, M. J., and B. G. Hogarth. 1983. Competitive interactions amongst four species of Glomus on maize and onion. Trans. Br. Mycol. Soc. 80:339-345.

Estrada-Luna, A. A., F. T. Davies, and J. N. Egilla. 2000. Mycorrhizal fungi enhancement of growth and gas exchange of micropropagated guava plantlets (Psidium guajava L.) during ex vitro acclimatization and plant establishment. Mycorrhiza 10:18.

Fox, R. L. 1981. External phosphorus requirements of crops. Pages 223-239 in R. H. Dowdy, J. A. Ryan, V. V. Volk, and D. E. Baker, eds. Chemistry in the soil environment. American Society of Agronomy, Madison, Wisconsin.

Fox, R. L., and E. J. Kamprath. 1970. Phosphate sorption isotherms for evaluating $\mathrm{P}$ requirements of soils. Soil Sci. Soc. Am. Proc. 34:902-907.

Gemma, J. N., and R. E. Koske. 1988. Preinfection interactions between roots and the mycorrhizal fungus, Gigaspora gigantea: Chemotropism of germ tubes and root growth response. Trans. Br. Mycol. Soc. 91:123-132.

1989. Field inoculation of American

beachgrass (Ammophila breviligulata) with VA mycorrhizal fungi. J. Environ. Manage. 29:173-182.

1997. Arbuscular mycorrhizae in sand dune plants of the North Atlantic coast of the U.S.: Field and greenhouse studies. J. Environ. Manage. 50:251-264.

Gemma, J. N., R. E. Koske, and T. Flynn. 1992. Mycorrhizae in Hawaiian pteridophytes: Occurrence and evolutionary significance. Am. J. Bot. 79:843-852.

Gemma, J. N., R. E. Koske, and M. Habte. 2002. Mycorrhizal dependency of some endemic and endangered Hawaiian plant species. Am. J. Bot. 89:337-345.

Gemma, J. N., R. E. Koske, E. M. Roberts, N. Jackson, and K. De Antonis. 1997. Mycorrhizal fungi improve drought resistance in creeping bentgrass. J. Turfgrass Sci. 73:15-29.

Gianinazzi-Pearson, V., S. Gianinazzi, and A. Trouvelot. 1985. Evaluation of the infectivity and effectiveness of indigenous vesicular-arbuscular mycorrhizal fungi populations in some agricultural soils in Burgundy. Can. J. Bot. 63:1521-1524.

Giovannetti, M., and B. Mosse. 1980. An evaluation of techniques for measuring vesicular arbuscular mycorrhizal infection in roots. New Phytol. 84:489-500.

Govindarajulu, M., P. E. Pfeffer, H. Jin, J. Abubaker, D. D. Douds, J. W. Allen, H. Bücking, P. J. Lammers, and Y. ShacharHill. 2005. Nitrogen transfer in the arbuscular mycorrhizal symbiosis. Nature (Lond.) 439:819-823.

Grime, J. P., J. M. L. Mackey, S. H. Hillier, and D. J. Read. 1987. Floristic diversity in a model system using experimental microcosms. Nature (Lond.) 328:420-422.

Habte, M., and B. N. Byappanhalli. 1998. Influence of pre-storage draying conditions and duration of storage on the effectiveness of root inoculum of Glomus aggregatum. J. Plant Nutr. 21:1375-1389.

Habte, M., R. L. Fox, and R. S. Huang. 1987. Determining vesicular-arbuscular mycorrhizal effectiveness by monitoring $\mathrm{P}$ status of subleaflets of indicator plants. Comm. Soil Sci. Plant Anal. 18:1403-1420.

Habte, M., and A. Manjunath. 1987. Soil solution phosphorus status and mycorrhizal dependency in Leucaena leucocephala. Appl. Environ. Microbiol. 53:797-801.

- 1991. Categories of vesiculararbuscular mycorrhizal dependency of host species. Mycorrhiza 1:3-12.

Henkel, T. W., W. K. Smith, and M. Christensen. 1989. Infectivity and effectivity of indigenous vesicular-arbuscular mycorrhizal fungi from contiguous soils in southwestern Wyoming, USA. New Phytol. 112:205-214.

Huang, R.-Y., R. S. Yost, R. L. Fox, M. Habte, and C. L. Murdoch. 1983. Effects of three mycorrhizal isolates of Leucaena leucocephala growth at three soil $\mathrm{pH}$ levels. Leucaena Res. Rep. 4:83-85. 
Huenneke, L. F., and P. M. Vitousek. 1990. Seedling and clonal recruitment of the invasive tree Psidium cattleianum: Implications for management of native Hawaiian forests. Biol. Conserv. 53:199-212.

Janos, D. P. 1980a. Vesicular-arbuscular mycorrhizae affect lowland tropical rain forest plant growth. Ecology 61:151-162.

- 1980b. Mycorrhizae influence tropical succession. Biotropica 12:56-64.

Korb, J. E., N. C. Johnson, and W. W. Covington. 2004. Slash pile burning effects on soil biota and chemical properties and plant establishment: Recommendations for amelioration. Restor. Ecol. 12:52-62.

Koske, R. E., and J. N. Gemma. 1989. A modified procedure for staining roots to detect V-A mycorrhizas. Mycol. Res. 92:486-488.

— 1995. Vesicular-arbuscular mycorrhizal inoculation of Hawaiian plants: A conservation technique for endangered tropical species. Pac. Sci. 49:181-191.

. 1996. Arbuscular-mycorrhizal fungi in Hawaiian sand dunes: Island of Kauai. Pac. Sci. 50:36-45.

_. 1997. Mycorrhizae and succession in plantings of beachgrass in sand dunes. Am. J. Bot. 84:118-130.

Koske, R. E., J. N. Gemma, and T. Flynn. 1992. Mycotrophy in Hawaiian angiosperms: A survey with implications for the origin of the native flora. Am. J. Bot. 79:853-862.

Lambert, D. H., H. Cole Jr., and D. E. Baker. 1980. Adaptation of vesicular-arbuscular mycorrhizae to edaphic factors. New Phytol. 85:513-520.

Langeland, K. A., and K. C. Burks. 1998. Identification and biology of non-native plants in Florida's natural areas. University of Florida, Gainesville.

Meharg, A. A. 2003. The mechanistic basis of interactions between mycorrhizal associations and toxic metal cations. Mycol. Res. 107:1253-1265.

Mehrhoff, L. A. 1996. Reintroducing endangered Hawaiian plants. Pages 101-120 in D. A. Falk, C. I. Millar, and M. Olwell, eds. Strategies for reintroduction of endangered plants. Island Press, Washington.
Miller, M. H. 2001. Arbuscular mycorrhizae and the phosphorus nutrition of maize: A review of Guelph studies. Can. J. Plant Sci. 80:47-52.

Miller, R. M. 1985. Mycorrhizae. Restor. Manage. Notes 3:14-20.

Miyasaka, S. C., and M. Habte. 2001. Plant mechanisms and mycorrhizal symbiosis to increase P uptake. Comm. Soil Sci. Plant Anal. 32:1101-1147.

Miyasaka, S. C., M. Habte, and D. T. Matsuyama. 1993. Mycorrhizal dependency of two Hawaiian endemic tree species: Koa and mamane. J. Plant Nutr. 16:1339-1356.

Moorman, T., and F. B. Reeves. 1979. The role of endomycorrhizae in revegetation practices in the semi-arid west. II. A bioassay to determine the effect of land disturbance on endomycorrhizal populations. Am. J. Bot. 66:14-18.

Plenchette, C., J. A. Fortin, and V. Furlan. 1983. Growth response of several plant species to mycorrhiza in a soil of moderate $\mathrm{P}$ fertility. I. Mycorrhizal dependency under field conditions. Plant Soil 70:191209.

Plenchette, C., V. Furlan, and J. A. Fortin. 1982. Effects of different endomycorrhizal fungi on five host plants grown on calcined montmorillonite clay. J. Am. Hortic. Sci. Soc. 107:535-538.

Pozo, M. J., C. Cordier, E. Dumas-Gaudot, S. Gianinazzi, J. M. Barea, and C. AzconAguilar. 2002. Localized versus systemic effect of arbuscular mycorrhizal fungi on defence responses to Phytophthora infection in tomato plants. J. Exp. Bot. 53:525534.

Read, D. A., and C. P. D. Birch. 1988. The effects and implications of disturbance of mycorrhizal mycelial systems. Proc. R. Soc. Edinb. Sect. B 94:13-24.

Reeves, F. B., D. Wagner, T. Moorman, and J. Kiel. 1979. The role of endomycorrhizae in revegetation practices in the semiarid west. I. A comparison of incidence of mycorrhizae in severely disturbed vs. natural environments. Am. J. Bot. 66:6-13.

Richter, B. S., and J. C. Stutz. 2002. Mycorrhizal inoculation of big sacaton: Im- 
plications for grassland restoration of abandoned agricultural fields. Restor. Ecol. 10:607-616.

SAS. 1999. Statview. SAS Institute, Cary, North Carolina.

Schmidt, S. K., and K. M. Scow. 1986. Mycorrhizal fungi on the Galapagos Islands. Biotropica 18:236-240.

Smith, C. W. 1985. Impact of alien plants on Hawai'i's native biota. Pages 180-250 in C. P. Stone and J. M. Scott, eds. Hawai'i's terrestrial ecosystems: Preservation and management. Cooperative Park Studies Unit, University of Hawai'i, Honolulu.

Smith, S. E., and D. J. Read. 1997. Mycorrhizal symbiosis. 2nd ed. Academic Press, London.

Stahl, P. D., M. Christensen, and S. E. Williams. 1990. Population variation in the mycorrhizal fungus Glomus mosseae: Uniform garden experiments. Mycol. Res. 94:1070-1076.

Stampe, E. D., and C. C. Daehler. 2003. Mycorrhizal species identity affects plant community structure and invasion: A microcosm study. Oikos 100:362-372.

St.-Arnaud, M., C. Hamel, M. Caron, and J. A. Fortin. 1994. Inhibition of Pytbium ultimum in roots and growth substrate of mycorrhizal Tagetes patula colonized with Glomus mosseae. Can. J. Plant Pathol. 16:187-194.

St. John, T. 1999. The role of mycorrhizae in regeneration of native vegetation. Pages 168-176 in B. G. Bowes, ed. A colour atlas of plant propagation and conservation. Manson Publ., London.

Sylvia, D. M., A. G. Jarstfer, and M. Vosatka. 1993. Comparison of vesicular-arbuscular mycorrhizal species and inocula formulations in a commercial nursery and on diverse Florida beaches. Biol. Fertil. Soils 16:139-144.

Thompson, J. P. 1994. Inoculation with vesicular-arbuscular mycorrhizal fungi from cropped soil overcomes long-fallow disorder of Linseed (Linum usitatissimum L.) by improving $\mathrm{P}$ and $\mathrm{Zn}$ uptake. Soil Biol. Biochem. 26:1133-1143.

Wagner, W. L., D. R. Herbst, and S. H. Sohmer. 1990. Manual of the flowering plants of Hawai'i. University of Hawai'i Press and Bishop Museum Press, Honolulu.

Zabinski, C. A., L. Quinn, and R. M. Callaway. 2002. Phosphorus uptake, not carbon transfer, explains arbuscular mycorrhizal enhancement of Centaurea maculos $a$ in the presence of native grassland species. Funct. Ecol. 16:758-765. 